\title{
PERBANDINGAN KEMAMPUAN PEMECAHAN MASALAH MATEMATIKA SISWA MENGGUNAKAN MODEL PEMBELAJARAN KOOPERATIF TIPE STAD DAN TIPE TPS
}

\author{
Dinda Syafrida ${ }^{1}$, Erlinawaty Simanjuntak ${ }^{2}$ \\ Pendidikan Matematika Universitas Negeri Medan \\ E-mail : dinda.syafrida@yahoo.com \\ E-mail : erlinawatys@yahoo.co.id
}

\begin{abstract}
ABSTRAK
Penelitian ini bertujuan untuk mengetahui apakah kemampuan pemecahan masalah matematika siswa yang belajar dengan menggunakan model pembelajaran kooperatif tipe STAD lebih tinggi dibandingkan dengan kemampuan pemecahan masalah matematika siswa yang belajar dengan menggunakan model pembelajaran kooperatif tipe TPS pada materi aturan sinus dan cosinus. Jenis penelitian ini adalah eksperimen semu dengan desain penelitian posttest Only Control Group Design. Populasi dalam penelitian ini adalah seluruh siswa kelas X-MIA SMA Negeri 3 Medan yang terbagi dalam 15 kelas dan yang menjadi sampel penelitian adalah 2 kelas yang dipilih dengan teknik cluster sampling yaitu kelas X MIA-4 menjadi kelas eksperimen 1 dengan menggunakan model pembelajaran kooperatif tipe STAD dan kelas X MIA-14 menjadi kelas eksperimen 2 dengan menggunakan model pembelajaran kooperatif tipe TPS. Sebelum pengujian hipotesis terlebih dahulu diuji normalitas data dengan menggunakan uji Liliefors dan homogenitas data menggunakan uji F. Setelah diberikan perlakuan pada kelas eksperimen 1 diperoleh nilai rata-rata posttest adalah 78,44 sedangkan pada kelas eksperimen 2 nilai rata-rata posttest adalah 71,75. Setelah diuji terbukti data berdistribusi normal dan homogen. Setelah data terbukti berdistribusi normal dan homogen dilakukan uji hipotesis untuk menjawab hipotesis penelitian dengan menggunakan uji $t$ pihak kanan. Dari hasil uji hipotesis diperoleh $t_{\text {hitung }}$ $(2,7347)>t_{\text {tabel }}(1,6646)$ maka $H_{a}$ diterima. Dengan demikian disimpulkan bahwa kemampuan pemecahan masalah matematika siswa yang belajar dengan menggunakan model pembelajaran kooperatif tipe STAD lebih tinggi dibandingkan dengan kemampuan pemecahan masalah matematika siswa yang belajar dengan menggunakan model pembelajaran kooperatif tipe TPS pada materi aturan sinus dan cosinus.
\end{abstract}

Kata kunci: Kemampuan Pemecahan Masalah Matematika, STAD, TPS

\begin{abstract}
The aim of this study were to know whether the problem solving skills of mathematics students who learn by using STAD type cooperative learning model is higher than the ability of problem solving mathematics students who learn by using cooperative learning model of TPS type on the material rules of sinus and cosine. This type of research is a pseudo experiment with posttest Only Control Group Design research design. The population in this research is all students of XMIA class X SMA Negeri 3 Medan which is divided into 15 classes and the research sample is 2 classes selected by cluster sampling technique that class X MIA-4 into experiment class 1 by using cooperative learning model type STAD and X class MIA-14 into experiment class 2 by using model of cooperative learning type of TPS. Before testing the hypothesis first tested the normality of the data by using the Liliefors test and homogeneity of data using the F test. After being given treatment in the experimental class 1 obtained the average value of posttest is 78.44 while in the experimental class 2 the average posttest value is 71.75 . After tested the data proved normal and homogeneous distribution. After the data proved to be normal and homogeneous distributions, hypothesis test is done to answer the research hypothesis by using the right side $t$ test. From result of hypothesis test obtained $t_{\text {count }}(2,7347)>t_{\text {table }}(1,6646)$ hence Ha accepted.
\end{abstract}


Thus it is concluded that the problem solving ability of mathematics of students who learn by using STAD type cooperative learning model higher than the ability of problem solving mathematics students who learn by using model of cooperative learning TPS type on the material rules of sinus and cosine.

Keywords: Mathematics Problem Solving Ability, STAD, TPS

\section{Pendahuluan}

Kemajuan sains dan teknologi yang begitu pesat dewasa ini tidak lepas dari peranan matematika. Matematika dalam dunia pendidikan telah menjadi perhatian utama dari berbagai kalangan, sehingga matematika menjadi bidang studi yang dipelajari oleh semua siswa pada setiap jenjang pendidikan. Matematika merupakan disiplin ilmu yang mempunyai peranan penting dalam menunjang kemajuan ilmu pengetahuan dan teknologi. Tujuannya tidak saja menambah ilmu pengetahuan guna mempersiapkan diri memasuki jenjang pendidikan yang lebih tinggi, tetapi juga berguna bagi kehidupan sehari-hari dan untuk ilmu pengetahuan lainnya. Hal ini memperlihatkan bahwa bidang studi matematika penting dalam pendidikan, dan sangat dibutuhkan dalam kehidupan.

Pembelajaran matematika tidak hanya diarahkan pada peningkatan kemampuan siswa dalam berhitung, tetapi juga diarahkan kepada peningkatan kemampuan siswa dalam pemecahan masalah. Berdasarkan hasil belajar matematika yang semacam itu maka Lerner (dalam Abdurrahman, 2009:253) mengemukakan bahwa kurikulum bidang studi matematika hendaknya mencakup tiga elemen, (1) konsep, (2) keterampilan, dan (3) pemecahan masalah.

Untuk itu maka kemampuan memecahkan masalah perlu menjadi fokus perhatian dalam pembelajaran matematika. Sebagaimana The National Council of Teachers of Mathematics (dalam Kurniawan, 2015: 67) menyatakan bahwa: "Problem solving should be the central focus of the mathematics curriculum. As such, it is a primary goal of all mathematics instruction and an integral part of all mathematical activity. Problem solving is not a distinct topic but a process that should permeate the entire program and provide the context in which concepts and skills can be learned."
Maknanya adalah pemecahan masalah harus menjadi fokus utama dari kurikulum matematika. Dengan demikian, pemecahan masalah adalah tujuan utama dari semua instruksi matematika dan merupakan bagian yang perlu dari semua aktivitas matematika. Pemecahan masalah bukanlah topik yang berbeda tetapi sebuah proses yang harus menembus seluruh program dan menyediakan konteks dimana konsep dan keterampilan dapat dipelajari.

Penggunaan model pembelajaran dalam menyajikan pelajaran sangat berpengaruh terhadap kemampuan pemecahan masalah. Sebagai pihak yang terlibat langsung dalam pembelajaran di kelas, guru matematika mempunyai peranan penting dalam mengadakan pembelajaran yang dapat mendukung siswa untuk mengembangkan kemampuan pemecahan masalah matematikanya. Guru diharapkan dapat menciptakan pembelajaran yang berpusat kepada siswa, membangkitkan aktivitas siswa dalam menggali pengetahuan dengan kemampuannya sendiri, yang bertujuan untuk mengembangkan kemampuannya dalam memecahkan masalah.

Model pembelajaran kooperatif dapat dijadikan model alternatif yang diharapkan dapat mengaktifkan siswa dalam proses belajar mengajar dan menyelesaikan masalah. Model pembelajaran kooperatif yang dapat dikembangkan dalam pembelajaran matematika diantaranya adalah model pembelajaran kooperatif tipe Student Teams Achievement Division (STAD) dan model pembelajaran kooperatif tipe Think Pair Share (TPS).

Student Teams Achievement Division (STAD) merupakan salah satu tipe pembelajaran kooperatif yang menekankan pada adanya aktivitas dan interaksi di antara siswa untuk saling memotivasi dan membantu

Dinda Syafrida, Erlinawaty Simanjuntak. Perbandingan Kemampuan Pemecahan Masalah Matematika Siswa Menggunakan Model Pembelajaran Kooperatif Tipe STAD dan Tipe TPS. Jurnal Inspiratif, Vol. 3 No. 1 April 2017. 
dalam menguasai materi pelajaran untuk mencapai prestasi yang maksimal (Isjoni, 2009: 74). Model pembelajaran ini diawali dengan penyampaian tujuan pembelajaran, penyampaian materi, kegiatan kelompok kuis, dan penghargaan kelompok (Istarani, 2011: 19).

Karakteristik dari STAD adalah untuk memotivasi siswa supaya saling mendukung dan membantu satu sama lain di dalam kelompoknya untuk mencapai satu penghargaan bersama. Dengan adanya penghargaan yang ingin dicapai secara tidak langsung akan memberikan dorongan dan motivasi lebih terhadap setiap anggota kelompok untuk lebih aktif dalam proses belajar dan berupaya lebih keras menyelesaikan suatu masalah yang diberikan. Hal ini berarti dengan adanya pemberian penghargaan terhadap keberhasilan kelompok dalam memecahkan masalah akan menjadi daya tarik dan motivasi terhadap siswa agar lebih aktif dalam kelompoknya untuk samasama berupaya lebih keras dalam mengembangkan kemampuannya memecahkan masalah.

Model pembelajaran kooperatif tipe Think Pair Share (TPS) membantu siswa menginterpretasikan ide mereka bersama dan memperbaiki pemahaman. Muhlisin, dkk (2013:41) menyatakan bahwa: "Think Pair Share (TPS) merupakan salah satu model pembelajaran kooperatif yang dapat digunakan untuk mendiskusikan suatu konsep matematika dengan prosedur berpikir, berpasangan (saling membantu) dan berbagi pendapat yang diharapkan dapat meningkatkan hasil belajar siswa di sekolah. Model ini memiliki prosedur yang ditetapkan secara eksplisit memberi waktu lebih banyak kepada siswa untuk berpikir, menjawab dan saling membantu satu sama lain."

Karakteristik dari TPS adalah adanya pemberian waktu untuk saling membantu dan berbagi ide dalam menyelesaikan masalah, yang memungkinkan siswa untuk lebih berpartisipasi aktif dalam proses belajar. Melalui pembelajaran kooperatif tipe TPS ini diharapkan siswa aktif berusaha mengembangkan kemampuannya dalam berbagi ide yang efektif untuk digunakan menyelesaikan masalah, sehingga secara tidak langsung siswa juga akan memperoleh pemahaman yang lebih besar dalam memecahkan masalah.

Berdasarkan uraian diatas diduga bahwa kemampuan pemecahan masalah matematika siswa yang belajar menggunakan model pembelajaran kooperatif tipe STAD lebih tinggi dibandingkan dengan kemampuan pemecahan masalah matematika siswa yang belajar menggunakan model pembelajaran kooperatif tipe TPS. Dikatakan demikian, sebab dalam model pembelajaran kooperatif tipe STAD adanya pemberian penghargaan terhadap keberhasilan kelompok dalam memecahkan masalah matematika yang diberikan, diharapkan dapat menjadi daya tarik bagi setiap siswa untuk lebih aktif dan memacu diri dalam mengembangkan kemampuan pemecahan masalahnya. Hal ini memungkinkan setiap siswa secara individual akan memiliki keberhasilan lebih banyak dalam memecahkan masalah matematika jika dibandingkan dengan pembelajaran kooperatif tipe TPS yang tidak terdapat pemberian penghargaan.

Rumusan masalah dari penelitian ini adalah apakah kemampuan pemecahan masalah matematika siswa yang belajar dengan menggunakan model pembelajaran kooperatif tipe STAD lebih tinggi dibandingkan dengan siswa yang belajar dengan menggunakan model pembelajaran kooperatif tipe TPS.

Sedangakan tujuan dari penelitian ini adalah untuk mengetahui apakah kemampuan pemecahan masalah matematika siswa yang belajar dengan menggunakan model pembelajaran kooperatif tipe STAD lebih tinggi dibandingkan dengan siswa yang belajar dengan menggunakan model pembelajaran kooperatif tipe TPS.

\section{Tinjauan Pustaka}

\section{A. Kemampuan Pemecahan Masalah Matematika}

Masalah yang dihadapi seseorang belum tentu menjadi masalah bagi orang lain. Hal ini disebabkan kemungkinan orang lain tersebut pernah mendapati dan memecahkan masalah seperti seseorang tersebut. Suatu masalah yang datang mengakibatkan orang tersebut agar berusaha untuk menyelesaikan masalah yang sedang dihadapinya. Sehingga dia harus

Dinda Syafrida, Erlinawaty Simanjuntak. Perbandingan Kemampuan Pemecahan Masalah Matematika Siswa Menggunakan Model Pembelajaran Kooperatif Tipe STAD dan Tipe TPS. Jurnal Inspiratif, Vol. 3 No. 1 April 2017 
menggunakan berbagai cara seperti berpikir, mencoba, dan bertanya untuk menyelesaikan masalahnya tersebut. Selain itu, memiliki kemampuan memecahkan masalah yang baik akan sangat berguna dalam kehidupan seharihari. Dengan demikian, kemampuan pemecahan masalah siswa menjadi suatu kebutuhan dan bagian dari tujuan pendidikan yang harus dicapai.

Conney (dalam Hudojo, 2005: 130) menyatakan bahwa mengajarkan penyelesaian masalah kepada peserta didik, memungkinkan peserta didik itu menjadi lebih analitis di dalam mengambil keputusan di dalam hidupnya. Dengan perkataan lain, bila peserta didik dilatih menyelesaikan masalah, maka peserta didik itu akan mampu mengambil keputusan, sebab peserta didik itu telah menjadi terampil tentang bagaimana mengumpulkan informasi yang relevan, menganalisis informasi, dan menyadari betapa perlunya meneliti kembali hasil yang telah diperolehnya.

Kirkley (2003: 3) menyatakan bahwa: "Problem solving shifted to represent a complex mental activity consisting of a variety of cognitive skills and actions." Maknanya, pemecahan masalah merupakan perwujudan dari suatu aktivitas mental yang terdiri dari bermacam-macam keterampilan dan tindakan kognitif.

Mayer (dalam Kirkley, 2003: 4) mendifinisikan bahwa problem solving as a multiple step process where the problem solver must find relationships between past experiences (schema) and the problem at hand and then act upon a solution. Maknanya adalah pemecahan masalah sebagai suatu proses banyak langkah dengan si pemecah masalah harus menemukan hubungan antara pengalaman (skema) masa lalunya dengan masalah yang sekarang dihadapinya dan kemudian bertindak untuk menyelesaikannya.

The National Council of Teachers of Mathematics (2000: 52) menyatakan bahwa: "Problem solving means engaging in a task for which the solution method is not known in advance. In order to find a solution, students must draw on their knowledge, and through this process, they will often develop new mathematical understandings. So, problem solving is an integral part of all mathematics learning, and it should not be an isolated part of the mathematics program."
Maknanya adalah pemecahan masalah merupakan proses melibatkan suatu tugas yang metode pemecahannya belum diketahui lebih dahulu, untuk mengetahui penyelesaiannya siswa hendaknya memetakan pengetahuan mereka, dan melalui proses ini mereka sering mengembangkan pengetahuan baru tentang matematika, sehingga pemecahan masalah merupakan bagian tak terpisahkan dalam semua bagian pembelajaran matematika, dan juga tidak harus diajarkan secara terisolasi dari pembelajaran matematika.

Berdasarkan beberapa pendapat tersebut, jelas bahwa pemecahan masalah adalah kompetensi strategik berupa aplikasi dari konsep dan keterampilan dalam memahami, memilih strategi pemecahan, dan menyelesaikan masalah, sedangkan kemampuan pemecahan masalah matematika merupakan kemampuan siswa untuk menyelesaikan atau menemukan jawaban dari suatu pertanyaan yang terdapat didalam suatu cerita, teks, dan tugas-tugas dalam pelajaran matematika sesuai langkah-langkah pemecahan masalah. Adapun kemampuan pemecahan masalah yang dimaksud dalam penelitian ini adalah kemampuan siswa dalam menyelesaikan soal-soal pemecahan masalah matematika sesuai dengan keempat langkahlangkah yang dinyatakan Polya. Sehingga indikator kemampuan pemecahan masalah matematika siswa dalam penelitian ini adalah:

1. Memahami masalah (understand the problem)

Pada langkah ini, siswa diharapkan dapat memahami permasalahan yang dihadapi. Kegiatan yang dilakukan siswa pada langkah ini, meliputi menuliskan bagian penting, hal yang tidak diketahui, data yang diketahui, dan syarat pada masalah. Selain itu, siswa juga menuliskannya dalam notasi matematika. Jika terdapat gambar terkait dengan masalah, siswa diharapkan dapat menggambarkannya.

2. Merencanakan penyelesaian (devise a plan)

Tahap ini dilaksanakan setelah siswa memahami masalah yang dihadapi. Pada tahap ini, siswa menyusun strategi atau rencana yang dapat digunakan untuk menyelesaikan masalah, yaitu siswa mampu menuliskan langkah-langkah apa yang seharusnya dikerjakan, termasuk di

Dinda Syafrida, Erlinawaty Simanjuntak. Perbandingan Kemampuan Pemecahan Masalah Matematika Siswa Menggunakan Model Pembelajaran Kooperatif Tipe STAD dan Tipe TPS. Jurnal Inspiratif, Vol. 3 No. 1 April 2017. 
dalamnya adalah menuliskan model atau rumus matematika.

3. Melaksanakan rencana penyelesaian (carry out the plan)

Pada tahap ini, siswa harus menuliskan rincian yang sesuai dengan garis besar rencana yang telah dibuat pada tahap sebelumnya untuk mendapatkan penyelesaian permasalahan, termasuk di dalamnya melakukan perhitungan dengan benar.

4. Melihat kembali (looking back)

Pada tahap ini, siswa mempertimbangkan kembali dan menguji kembali jawaban yang telah diperoleh dari tahap-tahap sebelumnya, sehingga siswa memiliki alasan yang kuat untuk mempercayai bahwa jawaban yang didapatkan benar dan menuliskan kesimpulan akhir.

\section{B. Model Pembelajaran Kooperatif}

Pembelajaran kooperatif adalah salah satu bentuk pembelajaran yang berdasarkan paham konstruktivis. Pembelajaran kooperatif merupakan strategi belajar dengan sejumlah siswa sebagai anggota kelompok kecil yang tingkat kemampuannya berbeda. Dalam menyelesaikan tugas kelompoknya, setiap siswa anggota kelompok harus saling bekerja sama dan saling membantu untuk memahami materi pembelajaran. Dalam pembelajaran kooperatif, belajar dikatakan belum selesai jika salah satu teman dalam kelompok belum menguasai bahan pelajaran (Isjoni, 2009: 14).

Selanjutnya Artz dan Newman (dalam Huda, 2011: 32) mendefinisikan bahwa: "Belajar kooperatif adalah suatu pendekatan yang mencakup kelompok kecil dari siswa yang bekerja sama sebagai suatu tim untuk memecahkan masalah, menyelesaikan suatu tugas, atau mencapai satu tujuan bersama."

Berdasarkan uraian di atas, model pembelajaran kooperatif merupakan pembelajaran dimana siswa belajar dan bekerja dalam kelompok kecil yang heterogen secara kolaboratif. Setiap siswa memiliki tanggung jawab terhadap setiap anggota kelompoknya dan saling membantu satu sama lain dalam rangka memperoleh hasil belajar yang optimal.

Jenis pembelajaran kooperatif yang digunakan dalam penelitian ini adalah model pembelajaran kooperatif tipe Student Teams
Achievement Division (STAD) dan tipe Think Pair Share (TPS).

\section{Model Pembelajaran Kooperatif Tipe STAD}

Model pembelajaran kooperatif tipe Student Teams Achievement Devision (STAD) ini dikembangkan oleh Slavin dan merupakan salah satu tipe kooperatif yang menekankan pada adanya aktivitas dan interaksi diantara siswa untuk saling memotivasi dan saling membantu dalam menguasai materi pelajaran guna mencapai prestasi yang maksimal (Isjoni, 2009: 74).

Slavin (dalam Trianto, 2011: 68) menyatakan bahwa: "Pada STAD siswa yang ditempatkan dalam belajar beranggotakan 4-5 orang yang merupakan campuran menurut tingkat prestasi, jenis kelamin dan suku. Guru menyajikan pelajaran, dan kemudian siswa bekerja dalam tim mereka memastikan bahwa seluruh anggota tim telah menguasai pelajaran tersebut. Kemudian, seluruh siswa diberikan tes tentang materi tersebut, pada saat tes ini mereka tidak diperbolehkan saling membantu."

Gagasan utama di balik model STAD adalah untuk memotivasi para siswa, mendorong dan membantu satu sama lain, dan untuk menguasai keterampilan-keterampilan yang disajikan oleh guru. Jika para siswa menginginkan agar kelompok mereka memperoleh penghargaan, mereka harus membantu teman sekelompoknya mempelajari materi yang diberikan. Mereka harus mendorong teman mereka untuk melakukan yang terbaik dan menyatakan bahwa belajar itu merupakan suatu yang penting, berharga, dan menyenangkan (Shoimin, 2016: 188-189).

Sintaks pelaksanaan pembelajaran kooperatif tipe STAD yang dikemukakan oleh Trianto (2011:71) terdiri atas 6 fase yaitu:

a. Fase - 1, menyampaikan tujuan dan memotivasi siswa

b. Fase - 2, menyajikan/menyampaikan informasi

c. Fase -3 , mengorganisasikan siswa dalam kelompok - kelompok belajar

d. Fase -4 , membimbing kelompok bekerja dan belajar

e. Fase -5, evaluasi

f. Fase -6 , memberikan Penghargaan

Dinda Syafrida, Erlinawaty Simanjuntak. Perbandingan Kemampuan Pemecahan Masalah Matematika Siswa Menggunakan Model Pembelajaran Kooperatif Tipe STAD dan Tipe TPS. Jurnal Inspiratif, Vol. 3 No. 1 April 2017 
Adapun kelebihan model pembelajaran kooperatif tipe STAD yang dikemukakan oleh Roestiyah (dalam Kholid, dkk., 2014: 358) adalah sebagai berikut:

1) Siswa diberi kesempatan besar untuk menggunakan keterampilan bertanya dan mendiskusikan masalah.

2) Siswa diberi kesempatan untuk melakukan investigasi masalah dengan lebih intensif.

3) Siswa dapat mengembangkan bakat kepemimpinan dan keterampilan mengajar dalam berdiskusi.

4) Guru lebih memperhatikan siswa secara individu.

5) Para siswa lebih aktif bergabung dalam pelajaran mereka dan mereka lebih aktif dalam berdiskusi.

6) Siswa diberi kesempatan untuk mengembangkan kemampuan dalam menilai dan menghormati pendapat orang lain.

Berdasarkan pernyataan di atas, terkait kelebihan model pembelajaran STAD yaitu siswa diberi kesempatan untuk menggunakan keterampilan bertanya dan mendiskusikan masalah, serta melakukan investigasi masalah dengan lebih intensif diharapkan dapat mengembangkan kemampuan siswa dalam memecahkan masalah. Selain itu, dengan adanya pemberian penghargaan pada pelaksanaan pembelajaran STAD diharapkan dapat memberikan dorongan dan motivasi lebih terhadap setiap anggota kelompok untuk lebih aktif dalam proses belajar dan berupaya lebih keras menyelesaikan suatu masalah yang diberikan. Penghargaan yang diberikan diharapkan dapat menjadi daya tarik bagi setiap siswa untuk lebih aktif dan memacu diri dalam mengembangkan kemampuan pemecahan masalah matematikanya.

\section{Model Pembelajaran Kooperatif Tipe TPS}

Melalui model pembelajaran kooperatif tipe think pair share dapat membantu peserta didik menginterpretasikan ide mereka bersama dan memperbaiki pemahaman. Dengan model pembelajaran ini, peserta didik lebih banyak memiliki kesempatan untuk berpartisipasi aktif sehingga peserta didik memperoleh pemahaman yang lebih besar.

Arends (dalam Trianto, 2011:81) menyatakan bahwa: "Think Pair Share merupakan suatu cara yang efektif untuk membuat variasi suasana pola diskusi kelas. Dengan asumsi bahwa semua resitasi atau diskusi membutuhkan pengaturan untuk mengendalikan kelas secara keseluruhan, dan prosedur yang digunakan dalam think pair share dapat memberi siswa lebih banyak waktu berpikir, untuk merespon dan saling membantu."

Selain itu Muhlisin, dkk (2013:41) menyatakan bahwa: "Think Pair Share (TPS) merupakan salah satu model pembelajaran kooperatif yang dapat digunakan untuk mendiskusikan suatu konsep matematika dengan prosedur berpikir, berpasangan (saling membantu) dan berbagi pendapat yang diharapkan dapat meningkatkan hasil belajar siswa di sekolah. Model ini memiliki prosedur yang ditetapkan secara eksplisit memberi waktu lebih banyak kepada siswa untuk berpikir, menjawab dan saling membantu satu sama lain.

Sintaks (langkah-langkah) pelaksanaan pembelajaran kooperatif tipe think pair share yang dikemukakan oleh Trianto (2011: 81-82) adalah sebagai berikut:

a. Langkah 1: Berpikir (Thinking)

Guru mengajukan suatu pertanyaan atau masalah yang dikaitkan dengan pelajaran, dan meminta siswa menggunakan waktu beberapa menit untuk berpikir sendiri jawaban atau masalah. Siswa membutuhkan penjelasan bahwa berbicara atau mengerjakan bukan bagian berpikir.

b. Langkah 2: Berpasangan (Pairing)

Selanjutnya guru meminta siswa untuk berpasangan dan mendiskusikan apa yang telah mereka peroleh. Interaksi selama waktu yang disediakan dapat menyatukan jawaban jika suatu pertanyaan yang diajukan atau menyatukan gagasan apabila suatu masalah khusus yang diidentifikasi. Secara normal guru memberi waktu tidak lebih dari 4 atau 5 menit untuk berpasangan.

c. Langkah 3: Berbagi (Sharing)

Pada langkah akhir, guru meminta pasangan-pasangan untuk berbagi dengan keseluruhan kelas yang telah mereka bicarakan. Hal ini efektif untuk berkeliling ruangan dari pasangan ke pasangan dan melanjutkan sampai sekitar sebagian

Dinda Syafrida, Erlinawaty Simanjuntak. Perbandingan Kemampuan Pemecahan Masalah Matematika Siswa Menggunakan Model Pembelajaran Kooperatif Tipe STAD dan Tipe TPS. Jurnal Inspiratif, Vol. 3 No. 1 April 2017. 
pasangan mendapat kesempatan untuk melaporkan.

Adapun kelebihan model pembelajaran kooperatif tipe think pair share menurut Istarani (2011 : 68) adalah sebagai berikut:

1) Dapat meningkatkan daya nalar siswa, daya kritis siswa, daya imajinasi siswa, dan daya analisis terhadap suatu permasalahan

2) Meningkatkan kerjasama antara siswa karena mereka dibentuk dalam kelompok

3) Meningkatkan kemampuan siswa dalam memahami dan menghargai pendapat orang lain.

4) Meningkatkan kemampuan siswa dalam menyampaikan pendapat sebagai implementasi ilmu pengetahuannya.

5) Guru lebih memungkinkan untuk menambahkan pengetahuan anak ketika selesai diskusi.

Berdasarkan pernyataan di atas, terkait kelebihan model pembelajaran TPS yang dapat meningkatkan daya nalar dan daya analisis siswa terhadap suatu permasalahan, diharapkan dapat mengembangkan kemampuan siswa dalam menyelesaikan masalah yang ada. Selain itu, dengan adanya pemberian waktu untuk saling membantu dan berbagi ide dalam menyelesaikan masalah, memungkinkan siswa akan lebih berpartisipasi aktif dalam proses belajar, sehingga diharapkan siswa aktif berusaha mengembangkan kemampuannya dalam berbagi ide yang efektif untuk digunakan menyelesaikan masalah.

Berdasarkan uraian-uraian yang telah dijelaskan sebelumnya diperoleh simpulan bahwa kemampuan pemecahan masalah matematika siswa yang belajar menggunakan model pembelajaran kooperatif tipe STAD lebih tinggi dibandingkan dengan yang belajar menggunakan model pembelajaran kooperatif tipe TPS. Dikatakan demikian, sebab dalam model pembelajaran kooperatif tipe STAD adanya pemberian penghargaan terhadap keberhasilan kelompok dalam memecahkan masalah yang diberikan, diharapkan dapat menjadi daya tarik bagi setiap siswa untuk lebih aktif dan memacu diri dalam mengembangkan kemampuan pemecahan masalahnya. Hal ini memungkinkan setiap siswa secara individual akan memiliki keberhasilan lebih banyak dalam memecahkan masalah matematika jika dibandingkan dengan pembelajaran kooperatif tipe TPS. Sedangkan dalam model pembelajaran kooperatif tipe TPS terdapat kegiatan saling membantu dan berbagi ide dalam menyelesaikan masalah bersama pasangannya. Ide yang dikembangkan setiap individu untuk menyelesaikan masalah terkadang memiliki batasan yang secara tidak langsung mengurangi minat dan kepercayaan diri siswa dalam berbagi ide dengan siswa lainya, sehingga memungkinkan siswa akan mengalami keterbatasan pula dalam mengembangkan kemampuan pemecahan masalahnya.

\section{Metode Penelitian}

Penelitian ini dilaksanakan di SMA Negeri 3 Medan yang berlokasi di Jalan Budi Kemasyarakatan No. 3 Medan pada semester genap tahun ajaran 2016/2017.

Populasi dalam penelitian ini adalah seluruh siswa kelas X-MIA SMA Negeri 3 Medan yang terdiri dari 15 kelas, sedangkan yang menjadi sampel dalam penelitian ini adalah kelas X MIA-4 yang terdiri dari 40 siswa sebagai kelas eksperimen 1 dan kelas $\mathrm{X}$ MIA-14 yang terdiri dari 40 siswa sebagai kelas eksperimen 2.

Variabel bebas dalam penelitian ini adalah pembelajaran kooperatif tipe STAD dan tipe TPS, sedangkan variabel terikatnya adalah kemampuan pemecahan masalah matematika siswa pada materi aturan sinus dan cosinus.

Jenis penelitian yang digunakan dalam penelitian ini adalah kuasi eksperimen yang bertujuan untuk mengetahui apakah kemampuan pemecahan masalah matematika siswa yang belajar dengan menggunakan model pembelajaran kooperatif tipe STAD lebih tinggi dibandingkan dengan siswa yang belajar dengan menggunakan model pembelajaran kooperatif tipe TPS.

Desain penelitian yang digunakan dalam penelitian ini adalah Posttest Only Control Group Design. Instrumen yang digunakan untuk memperoleh data dalam penelitian ini adalah posttest tes kemampuan pemecahan masalah matematika siswa yang terdiri dari empat butir soal berbentuk uraian. Analisis data dalam penelitian ini terdiri dari pengujian normalitas, pengujian homogenitas, dan pengujian hipotesis. 


\section{Hasil Penelitian}

Dari hasil postes diperoleh rata-rata posttest kelas eksperimen 1 dengan pembelajaran kooperatif tipe STAD adalah 78,44 , dengan nilai posttest tertinggi adalah 97,5 dan nilai posttest terendah adalah 50 . Sedangkan, rata-rata posttest kelas eksperimen 2 dengan pembelajaran kooperatif tipe TPS adalah 71,75 , dengan nilai posttest tertinggi adalah 95 dan nilai posttest terendah adalah 55 .

Setelah diperoleh nilai posttest siswa dari kedua kelas, selanjutnya ditentukan kriteria kemampuan pemecahan masalah dari setiap nilai posttest siswa tersebut.

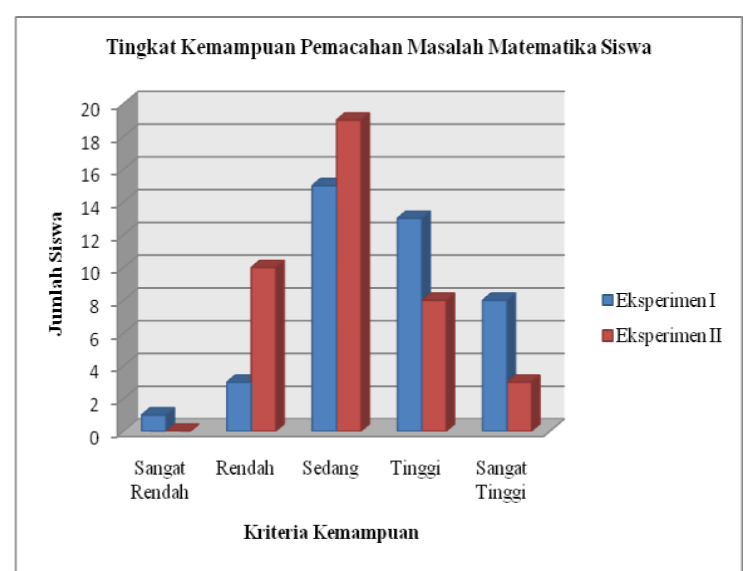

Gambar 1. Nilai Posttest siswa

Tingkat kemampuan pemecahan masalah matematika pada kategori "Tinggi" dan "Sangat Tinggi" lebih banyak diperoleh siswa kelas eksperimen 1. Sedangkan tingkat kemampuan pemecahan masalah matematika pada kategori "Rendah" dan "Sedang" lebih banyak diperoleh siswa kelas eksperimen 2 .

Dari perolehan nilai posttest kelas eksperimen 1 dan kelas eksperimen 2, selanjutnya juga dilakukan perhitungan terhadap perolehan nilai pada setiap aspek kemampuan pemecahan masalah matematika.

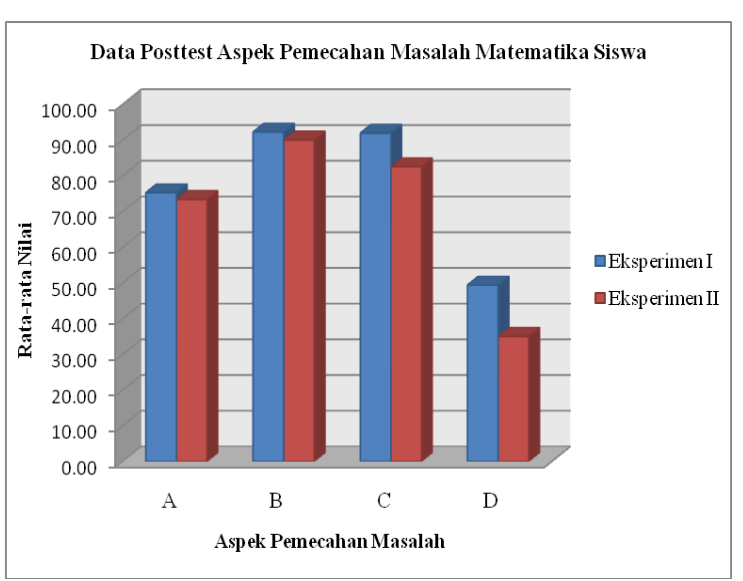

Gambar 2. Nilai setiap aspek kemampuan pemecahan masalah matematika

Pada setiap aspek kemampuan pemecahan masalah matematika, siswa kelas yang belajar dengan menggunakan model pembelajaran kooperatif tipe STAD memperoleh nilai ratarata yang lebih tinggi dibandingkan dengan siswa yang belajar dengan menggunakan model pembelajaran kooperatif tipe TPS.

Uji normalitas data nilai posttest siswa di kelas eksperimen 1 diperoleh $\mathrm{L}_{\text {hitung }}=0,0889$. Dengan $\alpha=0,05$ dan $\mathrm{n}=40$ diperoleh nilai kritis untuk uji Liliefors harga $\mathrm{L}_{\text {tabel }}=0,1401$. $\mathrm{L}_{\text {hitung }}(0,0889)<\mathrm{L}_{\text {tabel }}(0,1401)$, ini berarti data berdistribusi normal. Uji normalitas data nilai posttest siswa di kelas eksperimen 2 diperoleh $\mathrm{L}_{\text {hitung }}=0,1121$. Dengan $\alpha=0,05$ dan $\mathrm{n}=40$ diperoleh nilai kritis untuk uji Liliefors harga $\mathrm{L}_{\text {tabel }}=0,1401 . \mathrm{L}_{\text {hitung }}(0,1121)<\mathrm{L}_{\text {tabel }}(0,1401)$, ini berarti data berdistribusi normal.

Hasil perhitungan uji homogenitas data dengan menggunakan uji $\mathrm{F}$ diperoleh $F_{\text {hitung }}(1,0621)<F_{\text {tabel }}(1,697)$ yang berarti bahwa data nilai posttest kemampuan pemecahan masalah siswa dengan menggunakan pembelajaran kooperatif tipe STAD dan pembelajaran kooperatif tipe TPS dinyatakan memiliki varians yang sama atau homogen.

Berdasarkan hasil pengujian hipotesis pada taraf signifikansi $\alpha=0,05$ dan $\mathrm{dk}=\mathrm{n}_{1}+\mathrm{n}_{2}-2$ $=78$ dengan $t_{\text {hitung }}=2,7347$ dan $t_{\text {tabel }}=1,6646$ sehingga terlihat $t_{\text {hitung }}>t_{\text {tabel }}$ yaitu $2,7347>1,6646$ yang berarti bahwa $\mathrm{H}_{\mathrm{o}}$ ditolak dan $\mathrm{H}_{\mathrm{a}}$ diterima. Sehingga disimpulkan bahwa kemampuan pemecahan masalah matematika siswa yang belajar dengan menggunakan pembelajaran kooperatif tipe STAD lebih tinggi dibandingkan kemampuan pemecahan

Dinda Syafrida, Erlinawaty Simanjuntak. Perbandingan Kemampuan Pemecahan Masalah Matematika Siswa Menggunakan Model Pembelajaran Kooperatif Tipe STAD dan Tipe TPS. Jurnal Inspiratif, Vol. 3 No. 1 April 2017. 
masalah matematika siswa yang belajar dengan menggunakan pembelajaran kooperatif tipe TPS.

\section{Pembahasan}

Berdasarkan fakta yang ditemukan peneliti diperoleh bahwa siswa yang belajar dengan model pembelajaran kooperatif tipe STAD memiliki kemampuan pemecahan masalah yang lebih baik dibandingkan dengan siswa yang belajar dengan model pembelajaran kooperatif tipe TPS. Hal ini dikarenakan pada pembelajaran STAD siswa belajar dalam kelompok yang beranggotakan 5 orang yang heterogen dan pada pembelajaran ini ada pemberian penghargaan kepada kelompok yang dapat menyelesaikan masalah dengan baik, sehingga setiap siswa lebih bersemangat dalam memecahkan masalah. Sementara itu pada pembelajaran kooperatif tipe TPS siswa belajar dengan teman sebangkunya dan pada pembelajaran ini kegiatan diskusi siswa dalam mengembangkan dan bertukar ide untuk memecahkan masalah terkadang mengalami keterbatasan, yang secara tidak langsung juga mengganggu kegiatan siswa dalam memecahkan masalah.

Pada setiap aspek kemampuan pemecahan masalah matematika, siswa kelas eksperimen 1 atau yang belajar dengan menggunakan model pembelajaran kooperatif tipe STAD memperoleh nilai rata-rata yang lebih tinggi dibandingkan dengan siswa kelas eksperimen 2 atau yang belajar dengan menggunakan model pembelajaran kooperatif tipe TPS. Menurut Surya dan Rahayu (2014: 29) bahwa hal ini disebabkan karena dalam pembelajaran kooperatif tipe STAD terdapat belajar kelompok, sehingga siswa dapat bekerja sama dan saling membantu dalam mengatasi kesulitan-kesulitan yang dialaminya selama menyelesaikan permasalahan matematika. Dengan saling bekerja sama dan bertukar ideide matematika yang dimilikinya dapat melatih keterampilannya dalam memecahkan permasalahan matematika yang ada. Hal tersebut bermanfaat bagi siswa dalam meningkatkan kemampuan pemecahan masalah matematikanya.

Selain itu jika dilihat dari tingkat kemampuan pemecahan masalah matematika siswa dari kedua kelas juga memiliki perbedaan. Siswa yang belajar dengan menggunakan model pembelajaran kooperatif tipe STAD memiliki tingkat kemampuan pemecahan masalah yang lebih baik dibandingkan dengan siswa yang belajar dengan menggunakan model pembelajaran kooperatif tipe TPS. Hal ini dapat dilihat dari lebih banyaknya siswa yang tingkat kemampuan pemecahan masalah matematikanya berkategori tinggi dan sangat tinggi pada kelas STAD yakni 13 dan 8 siswa dibandingkan dengan kelas TPS yang banyaknya siswa dengan tingkat kemampuan pemecahan masalah matematika berkategori tinggi dan sangat tinggi lebih sedikit yakni 8 dan 3 siswa.

\section{Kesimpulan}

Adapun yang menjadi kesimpulan dalam penelitian ini adalah:

Kemampuan pemecahan masalah matematika siswa yang belajar dengan menggunakan model pembelajaran kooperatif tipe STAD lebih tinggi dibandingkan dengan kemampuan pemecahan masalah matematika siswa yang belajar dengan menggunakan model pembelajaran kooperatif tipe TPS pada materi aturan sinus dan cosinus di kelas $\mathrm{X}$ SMA Negeri 3 Medan, hal ini dibuktikan dari hasil pengujian hipotesis dimana $t_{\text {hitung }}>t_{\text {tabel }}$ yaitu $2,7347>1,6646$. Pada setiap aspek kemampuan pemecahan masalah matematika, siswa yang belajar dengan menggunakan model pembelajaran kooperatif tipe STAD memperoleh nilai rata-rata yang lebih tinggi dibandingkan dengan siswa yang belajar dengan menggunakan model pembelajaran kooperatif tipe TPS.

\section{Saran}

Berdasarkan hasil penelitian ini, saran yang dapat diajukan peneliti adalah:

1) Bagi guru khususnya matematika diharapkan untuk dapat menggunakan model pembelajaran kooperatif tipe STAD dan tipe TPS pada proses belajar mengajar

Dinda Syafrida, Erlinawaty Simanjuntak. Perbandingan Kemampuan Pemecahan Masalah Matematika Siswa Menggunakan Model Pembelajaran Kooperatif Tipe STAD dan Tipe TPS. Jurnal Inspiratif, Vol. 3 No. 1 April 2017 
dalam membuat siswa lebih aktif pada proses pembelajaran.

2) Bagi guru matematika yang ingin meningkatkan kemampuan pemecahan masalah matematika siswa, model pembelajaran STAD adalah pilihan yang tepat hal ini dikarenakan model STAD melatih siswa untuk berinteraksi supaya saling memotivasi dan membantu satu sama lain dalam memahami pelajaran dan adanya pemberian penghargaan membuat siswa lebih bersemangat dan lebih bertanggung jawab terhadap kelompoknya untuk mencapai kesuksesan memecahkan masalah.

3) Bagi calon peneliti berikutnya agar mengadakan penelitian yang sama namun dengan materi dan tingkatan kelas yang berbeda sehingga hasil penelitian dapat berguna bagi kemajuan pendidikan khususnya pendidikan matematika.

\section{DAFTAR PUSTAKA}

Abdurrahman, Mulyono., (2009), Pendidikan Bagi Anak Berkesulitan Belajar, PT Rineka Cipta, Jakarta.

Huda, Miftahul., (2011), Cooperative Learning: Metode, Teknik, Struktur, Dan Model Penerapan, Pustaka Pelajar, Yogyakarta.

Hudojo, Herman., (2005), Pengembangan Kurikulum dan Pembelajaran Matematika, Universitas Negeri Malang, Malang.

Isjoni, (2009), Pembelajaran Kooperatif, Pustaka Pelajar, Yogyakarta.

Istarani, (2011), 58 Model Pembelajaran Inovatif, Media Persada, Medan.

Kholid, dkk., (2014), Learning Model Experimentation Of Student Team Achievement Division (STAD) And Think Pair Share (TPS) Of Assessment For Learning (AFL) Based, Proceeding of International Conference On Research Implementation And Education Of
Mathematics And Sciences 2014, ISBN 978-979-99314-8-1, Hal 355-362.

Kirkley, Jamie.. (2003), Principles for Teaching Problem Solving, Technical Paper \#4, Plato Learning, Indiana University.

Kurniawan, Heru., (2015), Analisis Keterampilan Pemecahan Masalah Pada Pembelajaran Matematika, Prosiding Seminar Nasional Pendidikan November 2015, ISBN: 978-979-3456-52-2, Hal 67-73.

Muhlisin, dkk., (2013), Keefektifan Pembelajaran Model TPS Berbantuan GSP Pada Pencapaian Kemampuan Pemecahan Masalah, Unnes Journal of Mathematics Education, Vol. 1, No. 2, ISSN: 2252-6927, Hal 41-48.

Polya, G., (2001), How to Solve it A New Aspect of Mathematical Method Second Edition, Prentice Hall of India Private Limited, New Delhi.

Shoimin, Aris., (2016), 68 Model Pembelajaran Inovatif dalam Kurikulum 2013, Ar-Ruzz Media, Yogyakarta.

Trianto, (2011), Mendesain Model Pembelajaran Inovatif-Progresif, Kencana Prenada Media Group, Jakarta.

Dinda Syafrida, Erlinawaty Simanjuntak. Perbandingan Kemampuan Pemecahan Masalah Matematika Siswa Menggunakan Model Pembelajaran Kooperatif Tipe STAD dan Tipe TPS. Jurnal Inspiratif, Vol. 3 No. 1 April 2017. 